\title{
RECRUTAMENTO, VALORES E PADRÕES DE AÇÃO POLÍTICA DA ELITE EMPRESARIAL
}

\author{
Paulo Roberto Neves \\ Costa
}

\author{
Tiago Junior Roks
}

\author{
Guatimozin de Oliveira \\ Santos Filho
}

\begin{abstract}
RESUMO
O objetivo deste artigo é analisar as características da elite empresarial no Paraná. O uso de metodologias típicas dos estudos sobre elites e sobre cultura política, articuladas à análise da forma como se daria a ação política, permitiu uma melhor caracterização dos representantes políticos do empresariado e, em particular, no que diz respeito à sua relação com a democracia e o funcionamento de suas instituições. Tal relação é considerada em um nível fundamental do funcionamento da política brasileira, o estadual. Entre 2010 e 2011, foram realizadas entrevistas com os principais dirigentes das entidades mais importantes na representação do empresariado paranaense. Além das informações sobre as trajetórias social, educacional e política, o questionário buscou levantar também as justificativas das opiniões, das avaliações e dos padrões de ação política. Constatamos que, de um lado, existe certa homogeneidade no que diz respeito às trajetórias e certa coesão em relação aos valores políticos, à avaliação sobre as instituições democráticas e aos padrões de ação política por parte da elite empresarial paranaense. Além da total adesão à democracia, há um relativo grau de satisfação com suas instituições, o que revela algumas características das relações dessa elite e de seus representados com a política e a democracia, e como, nesse aspecto, ela também se distingue da população em geral.
\end{abstract}

PALAVRAS-CHAVE: empresariado; elite empresarial do Paraná; instituições democráticas; cultura política; comportamento político.

\section{INTRODUÇÃO ${ }^{1}$}

A questão sobre a qual se apóia a pesquisa subjacente a este artigo é a relação entre empresariado e regime político democrático. Tomamos como objeto aqueles que dirigem as entidades de representação empresarial, a elite político-representativa do empresariado, aqui chamada de elite empresarial. Levamos em conta os processos de representação política e de ação política como critérios de recorte para a análise do empresariado. Tal elite é, então, considerada

1 A pesquisa subjacente a este artigo faz parte das atividades relacionadas à Bolsa Produtividade em Pesquisa (PQ) do Conselho Nacional de Desenvolvimento Científico e Tecnológico (CNPq), para o qual expressamos nossos agradecimentos, e também do Núcleo de Pesquisa em Sociologia Política Brasileira (NUSP) da Universidade Federal do Paraná (UFPR). Agradecemos fortemente aos entrevistados pela disposição em participar de nossa pesquisa. Também agradecemos aos pareceristas anônimos da Revista de Sociologia e Política por sua contribuição para este artigo. não apenas um agente econômico, mas, sobretudo, político, em suas relações com a democracia e suas instituições ${ }^{2}$. Para tanto, articulamos problemas e métodos característicos dos estudos de elites políticas, cultura política e ação política.

Em suma, pretendemos analisar a formação e o comportamento de representantes políticos do empresariado e a sua relação com a democracia brasileira, estabelecida por meio de parte de seus representantes formalmente estabelecidos. Em paralelo, pretendemos contribuir, assim, para uma Sociologia Política da democracia brasileira.

Consideramos três dimensões fundamentais e ainda não suficientemente estudadas: (i) a relação entre elites políticas e democracia; (ii) a relação entre empresários e o regime democrático e (iii)

2 Os fundamentos dessas proposições foram desenvolvidos em trabalhos anteriores. Para maiores detalhes sobre suas implicações teóricas e metodológicas, ver Costa (2005a; 2005b; 2007; 2012) e Costa e Engler (2008). 
um âmbito específico do funcionamento desse regime político no Brasil, ou seja, o nível estadual. Além disso, pelo fato de tratar-se de dirigentes de entidades de representação, pretendemos contribuir também para a análise do funcionamento das entidades de representação empresarial, um objeto fundamental para o tratamento de questões relativas à ação coletiva e à organização institucional dos mercados (OFFERLÉ, 2009).

Verificamos que, de um lado, a elite empresarial paranaense é homogênea em seus atributos adstritos e adquiridos, coesa em relação aos valores políticos relacionados à democracia e coesa também em relação aos padrões de ação política em dados processos decisórios $\operatorname{concretos}^{3}$; ressalvando-se, desde já que, no empresariado, a coesão em relação aos padrões de ação política não é sinônimo de ação conjunta ou convergente. Por outro lado, ao lado da alta adesão à democracia, essa elite encontra-se relativamente mais satisfeita com as instituições da democracia brasileira e, embora pouco interessada em atuar efetivamente no aperfeiçoamento da democracia no país, colocase entre as bases sociais desse regime político, em especial no âmbito local (estadual) de seu funcionamento.

Após breves comentários sobre os aspectos metodológicos, as características gerais da economia paranaense nos últimos anos e as entidades contempladas pela pesquisa, apresentaremos os dados sobre o processo de recrutamento, os valores políticos e os padrões de ação política da elite empresarial paranaense. Em seguida, faremos a análise dos dados e apresentaremos nossas principais conclusões.

\section{BREVES NOTAS METODOLÓGICAS}

Os dados que sustentam este artigo referemse à pesquisa "Elite empresarial e democracia no Brasil: questões de teoria e método", vinculada

\footnotetext{
3 Estamos referindo-nos às semelhanças em relação aos aspectos que Suzanne Keller chama de "atributos adstritos" as "características que diferenciam os indivíduos e que [...] permanecem continuamente vinculadas a eles", por exemplo, gênero, etnia e religião, e de "atributos adquiridos", aqueles que são conquistados ou valorizados ao longo da vida, por exemplo, a profissão e as trajetórias educacional e política (KELLER, 1971, p. 160). Por "coesão" estamos referindo-nos às proximidades e semelhanças que podem dar-se tanto em relação aos valores quanto aos padrões de ação política.
}

ao Núcleo de Pesquisa em Sociologia Política Brasileira da UFPR, realizada em 2010 e 2011, que tratou de questões relativas à elite empresarial brasileira, nos níveis nacional e estadual, em especial no Paraná. O questionário utilizado (ver Anexo 1) continha questões fechadas e abertas, e buscou mobilizar variáveis de natureza qualitativa, ou seja, não apenas as opiniões e declarações, mas também as justificativas que as sustentariam, dando um rendimento analítico nem sempre encontrado nas pesquisas que utilizam o survey como metodologia.

O questionário foi dividido em três blocos: $(i)$ perfil e trajetória política; (ii) cultura política e atitudes e (iii) ação política e comportamento. No bloco de perfil e trajetória foram analisados itens relativos aos estudos sobre recrutamento, elaborado a partir das seguintes questões: data e local de nascimento, religião, cor ou raça, ocupação, nível de escolaridade, ocupação e nível de escolaridade do pai, ocupação de cargos públicos (eletivos ou não), se é ou foi presidente ou membro de outras entidades e se é ou foi filiado a partidos políticos. No bloco sobre cultura política, os seguintes pontos foram abordados: concepção sobre os aspectos gerais da democracia, avaliação do funcionamento das instituições democráticas, grau de confiança nas relações políticas e empresariais, consolidação da democracia no Brasil e a reforma política. O último bloco voltou-se para os padrões de ação política, abordando questões que nos permitissem captar alguns aspectos do comportamento político das entidades. Abordamos, nesse ponto, questões sobre representação dos interesses, relações entre as entidades e as instituições estatais, incluindo o lobby, e a forma de ação das entidades no contexto das eleições de 2010. Ainda em relação aos padrões de ação política, averiguamos os aspectos gerais de suas estratégias de defesa de interesses frente ao conjunto do empresariado e ao Estado, mas também de sua atuação em processos decisórios concretos. Apresentaremos os dados de maneira agregada, sem a identificação dos entrevistados, conforme foi assegurado aos participantes.

Quanto ao objeto, o uso do método posicional (MILLS, 1981) pela pesquisa subjacente a este artigo levou-nos a identificar os membros da elite empresarial a partir da posição que ocupam nas entidades. Dessa forma, contemplamos os principais dirigentes (presidentes e diretores) das 
mais importantes entidades de representação de interesses de diversos setores empresariais do estado do Paraná, tanto de caráter sindical quanto associativo, e as características da economia local ${ }^{4}$. Além das entidades mais convencionais, acrescentamos as Câmaras de Comércio, dada sua importância em relação às atividades voltadas para o comércio exterior (importação e exportação) e à internacionalização da economia paranaense (investimentos estrangeiros no estado e investimento nacional em outros países). Por fim, além da diversidade das entidades contempladas, conseguimos contemplar cinco das oito que compõem o grupo de atuação empresarial chamado de "G8"

Quando consideramos a economia paranaense nos últimos 40 anos, verificamos que houve um processo de profunda transformação em sua estrutura produtiva. A Companhia de Desenvolvimento Econômico do Paraná (Codepar), posteriormente transformada no Banco de Desenvolvimento Econômico do Paraná (Badep), estimulou a industrialização no estado, porém, concentrando seus investimentos em setores nos quais a indústria paranaense apresentava-se competitiva, assim como na abertura de espaços para a instalação de grandes empresas ligadas a oligopólios e ao capital estrangeiro. Outras iniciativas, como a consolidação da Cidade Industrial de Curitiba (CIC), o primeiro grande projeto de desenvolvimento no Paraná, que uniu interesses da classe política dirigente e do empresariado local, foram também fundamentais para que o governo estadual pudesse consolidar uma agressiva agenda focada na atração de investimentos (OLIVEIRA, 2001).

Ocorreu também uma diversificação na base produtiva do setor industrial, o que implicou uma mudança de direcionamento da agroindústria, por meio da atuação em mercados externos. A

4 Além das entidades contempladas pela pesquisa, outras inicialmente previstas não se dispuseram a participar, a saber, Associação Comercial do Paraná, Associação dos Dirigentes de Empresas do Mercado Imobiliário no Estado do Paraná, Associação Paranaense de Supermercados e Federação das Empresas de Transporte de Cargas do Estado do Paraná. Em relação a esse aspecto, vale a pena lembrar o que Offerlé fala sobre este tipo de pesquisa, ou seja, que o afastamento dos sociólogos em relação à produção industrial adotou também um caráter mais dinâmico, buscando gerar produtos com maior conteúdo tecnológico, como materiais elétricos, comunicações, transporte e mecânica (CASTRO \& VASCONCELOS, 1999). Tal período caracterizou-se como o momento de consolidação do parque industrial do Paraná, o qual serviu como base para a sua reestruturação econômica ocorrida na década de 1990 (MIGLIORINI, 2006). Essa época ficou marcada também por uma maior integração da produção paranaense junto a mercados nacionais e internacionais (TRINTIN, 2001). Além disso, o setor industrial paranaense é responsável por pouco mais de $20 \%$ do produto interno bruto (PIB) estadual (IPARDES, 2011).

Em relação ao setor de serviços, nos últimos anos, a evolução do crescimento da produção interna bruta foi mais constante e estável do que aquela verificada nos outros setores econômicos. Como indica a Tabela 1, o setor de serviços no Paraná compõe cerca de $70 \%$ do PIB estadual e,

realidade das empresas é equivalente à ignorância dos chefes de empresa da realidade das pesquisas em Ciências Sociais (OFFERLÉ, 2009).

5 Existe no Paraná um grupo informal de entidades de representação empresarial identificado como "G8". Não existe nenhum acordo formal ou legal que sustente a existência dessa coalizão. Porém, o grupo reúne-se frequentemente para discutir assuntos relacionados ao setor produtivo paranaense, como infraestrutura e tributação, junto ao governo estadual, sendo composto por Faciap (Federação das Associações Comerciais e Empresariais do Paraná), Ocepar (Organização das Cooperativas do Estado do Paraná), Faep (Federação da Agricultura do Estado do Paraná), Fecomércio (Federação do Comércio do Paraná), Fiep (Federação das Indústrias do Estado do Paraná), Fetranspar (Federação das Empresas de Transporte de Cargas do Estado do Paraná), Associação Comercial do Paraná (A CP) e Fampepar (Federação das Associações de Micro e Pequenas Empresas). Além disso, tais entidades alternam o comando do Conselho de Administração do Sebrae no Paraná, o que representa um orçamento de R\$ 160 milhões por biênio, sendo que o Sebrae, não só por sua capilaridade, mas também pelo seu próprio escopo de atuação, é um dos programas com maior penetração junto ao pequeno empresário paranaense e brasileiro, com óbvias implicações econômicas e políticas no estado. O G8 tem não apenas ações reativas, mas também propositivas, em âmbito estadual. Mobilizou-se em torno da criação do Conselho de Desenvolvimento do Paraná, da proposta de auditoria sobre as empresas de pedágio, e tem tido atuação importante no debate sobre o reajuste anual do salário mínimo regional. 
portanto, está muito bem assentado, representando a maior parte das riquezas produzidas no estado.

\section{TABELA 1 - COMPOSIÇÃO DO PIB DO PARANÁ}

\begin{tabular}{|l|c|}
\hline SETOR & PARTICIPAÇÃO (\%) \\
\hline Serviços & 68,62 \\
Indústria & 21,76 \\
Agricultura & 9,62 \\
TOTAL & 100 \\
\hline
\end{tabular}

FONTE: IBGE (2011).

No começo do ano de 2011, as vendas do comércio no Paraná aumentaram 11,98\%, um crescimento maior do que o registrado pela economia do estado como um todo (idem). Três subsetores destacam-se:

\section{TABELA 2 - SERVIÇOS: SUBSETORES MAIS} DINÂMICOS (\%)

\begin{tabular}{|lr|}
\hline Comércio e serviços de reparação & 30 \\
Administração, saúde e educação públicas & 17 \\
Atividades imobiliárias e de aluguel & 12 \\
Outros & 41 \\
\hline
\end{tabular}

FONTE: Ipardes (2011).

A agropecuária paranaense diversificou a produção e aumentou a produtividade em função da sua modernização e dos bons preços internacionais praticados. Outro ponto importante diz respeito à força econômica e política consolidada pelas cooperativas desse setor no estado, nos últimos 20 anos. Com uma participação média de $10 \%$ no agronegócio brasileiro, o Paraná é o maior exportador mundial de grãos e o maior produtor de bens florestais no país. A agroindústria do estado está baseada em alimentos e bebidas, e sua participação em tais segmentos é em média de $9,2 \%$ da produção de todo o país (idem).

Desde 1971, o estado conta com a Organização das Cooperativas do Estado do Paraná (Ocepar), que representa esse ramo de atividade econômica. Atualmente, existem 238 cooperativas no estado, das quais 82 são cooperativas do ramo agropecuário. O número de cooperados no ramo é muito próximo de 300000 produtores rurais. E as cooperativas agrícolas são responsáveis por $56 \%$ da produção agrícola do Paraná (OCEPAR, 2011).

Em relação à economia nacional, o Paraná é o quinto estado com maior produção industrial, e o segundo na região Sul do país, à frente de estados como Santa Catarina, Espírito Santo e Amazonas. $\mathrm{O}$ crescimento médio da indústria paranaense é de uma taxa de 2,7\% ao ano, uma média superior ao nível nacional para o ano de 2011, que foi de 1,8\% (IPARDES, 2011). Em 2010, o Paraná foi o quinto estado brasileiro em exportação, quando as exportações contabilizaram cerca de US $\$ 14,2$ bilhões, um crescimento de $26,3 \%$ em relação a 2009 e que representa $7 \%$ do total nacional. Os principais parceiros comerciais são China, Argentina, Alemanha, Países Baixos e Estados Unidos (BRASIL. MDIC, 2011).

TABELA3 - EXPORTAÇÃO DO PARANÁ: PRINCIPAIS PRODUTOS EXPORTADOS

\begin{tabular}{|l|c|c|c|}
\hline PRODUTO & $\begin{array}{c}\text { VALOR EXPORTADO } \\
\text { (US\$ MILHÕES FOB) }\end{array}$ & $\begin{array}{c}\text { PARTICIPAÇÃO NAS } \\
\text { EXPORTAÇÕES (\%) }\end{array}$ & $\begin{array}{c}\text { TONELAGEM } \\
\text { (1 000 000 KG) }\end{array}$ \\
\hline Grãos de soja & 2372,6 & 16,74 & 6280,5 \\
Açúcar de cana & 1057,5 & 7,46 & 2509,3 \\
Bagaço e resíduos de soja & 1042,6 & 7,35 & 2907,6 \\
Carne de frango & 873,4 & 6,16 & 510,0 \\
Automóveis & 770,8 & 5,44 & 83,1 \\
Outros produtos & 8059,2 & 56,85 & 8031,6 \\
\hline
\end{tabular}

FONTE: BRASIL. MDIC (2011).

Levando em consideração os dados acima apresentados, procuramos selecionar para este trabalho um grupo de entidades empresariais que representassem historicamente importantes 
setores e atividades econômicas do estado do Paraná, no caso, indústria, serviços, e agricultura. $\mathrm{O}$ primeiro setor foi contemplado por meio da análise dos dados referentes à entidade patronal a ele relacionada

Da mesma forma, em relação à agricultura, levamos em consideração não só a entidade patronal que representa o interesse dos agricultores, mas também a força e a dimensão que as cooperativas representam no Paraná. Em relação ao processo de internacionalização da economia paranaense, que tomou grandes proporções ao fim da década de 1980, selecionamos duas entidades que são consideradas as mais representativas em relação ao comércio exterior e atração de capital estrangeiro. $\mathrm{O}$ setor de serviços, em grande medida representado pelo comércio, mas que também engloba outras atividades como os seguros, foi também contemplado em nossa pesquisa. E, apesar da grande concentração do PIB paranaense em Curitiba e Região Metropolitana (Tabela 4), procuramos contemplar entidades localizadas nessa região que também tivessem capilaridade em outras partes do estado.

\begin{tabular}{|c|c|}
\hline & \\
\hline & \\
\hline Região Metropolitana de Curitiba & 44,24 \\
\hline Interior e Litoral & 55,76 \\
\hline Total & 100 \\
\hline
\end{tabular}

Fonte: IBGE (2011).

Abaixo seguem as entidades contempladas através de seus dirigentes, por ordem alfabética. Cabe ressaltar que a caracterização das mesmas seguiu a maneira pela qual cada uma oficialmente se define em termos de atuação e representação.

-AHK: Câmara de Indústria e Comércio BrasilAlemanha. As câmaras de comércio e indústria Brasil-Alemanha atuam há quase 90 anos no país, promovendo a colaboração entre as economias da Alemanha e do Brasil. Aproximadamente 1500 empresas são associadas às Câmaras. A AHK contempla tanto firmas de capital e know-how alemães quanto empresas brasileiras ligadas ao comércio exterior, além de empresas e instituições radicadas na Alemanha. A proximidade com empresas, órgãos públicos e associações no Brasil e na Alemanha faz com que as câmaras possam prestar serviços importantes, que facilitam o acesso aos mercados brasileiro e sul-americano, bem como ao alemão e europeu.

- Amcham: Câmara Americana de Comércio. A Amcham é considerada a maior câmara de comércio do mundo. Fundada em 1919 e com mais de cinco mil empresas associadas espalhadas em onze unidades regionais, procura oferecer aos seus associados espaços de relacionamento, oportunidades de capacitação e representação direta dos interesses das empresas associadas junto ao governo. No Paraná, é considerada a maior entidade multisetorial do Estado e conta com mais de 400 empresas em sua base de associados.

- Apeop: Associação Paranaense dos Empresários de Obras Públicas. A Apeop é uma sociedade civil sem fins lucrativos, fundada em 1960, e representa o setor de empreiteiras e infraestrutura junto ao Estado.

- Faciap: Federação das Associações Comerciais e Empresariais do Estado do Paraná. Fundada em 1959, representa 288 associações comerciais às quais estão vinculadas mais de 40 mil empresas em todo o estado. A entidade é uma das maiores instituições do sistema no Brasil, com atuação em $75 \%$ dos municípios paranaenses. As associações comerciais e empresariais filiadas à Faciap estão presentes nas principais cidades, que representam juntas $95 \%$ do PIB paranaense.

- FAEP: Federação da Agricultura do Estado do Paraná. A FAEP tem como objetivo a coordenação, a defesa e a representação legal da agricultura e da pecuária, com 178 sindicatos em todo o estado. Mantida pelos produtores rurais, faz parte do Sistema Sindical Rural e está integrada à Confederação Nacional da Agricultura.

- Fecomercio: Federação do Comércio do Estado do Paraná. Fundada em 1948, a Fecomercio administra os serviços sociais e de aprendizagem comercial no Paraná, o SESC e o Senac. Atualmente possui 51 sindicatos filiados, que correspondem a aproximadamente 400000 estabelecimentos comerciais existentes no estado do Paraná.

- FIEP: Federação das Indústrias do Estado do Paraná. A FIEP é a quinta maior federação regional do Brasil, conta com 107 sindicatos aos quais estão ligadas mais de 42 mil indústrias. A 
entidade ocupa papel relevante na composição da CNI e atua em várias frentes, inclusive desenvolvendo projetos inovadores relacionados à mobilização e à valorização da participação política da população em geral ${ }^{6}$.

- Ocepar: Sindicato e Organização das Cooperativas do Estado do Paraná. A Ocepar é uma cooperativa criada em 1971, integrante da Organização das Cooperativas do Brasil (OCB) e que visa desenvolver, representar e defender os interesses do sistema cooperativista paranaense. A Ocepar passou também a exercer funções de sindicato patronal das cooperativas paranaenses desde 1997. Possui, em sua estrutura, 238 cooperativas registradas, que reúnem mais de 535 mil associados.

- Sindiseg: Sindicato das Empresas de Seguros Privados, Resseguros, de Previdência Complementar e de Capitalização nos Estados do Paraná e do Mato Grosso do Sul. Filiado à Federação Nacional de Seguros Gerais (Fenseg), o Sindiseg PR-MS tem como objetivo oferecer suporte às empresas seguradoras do Paraná e representar os interesses das empresas filiadas junto ao poder público. Possui, em sua base de filiados, mais de 20 grandes seguradoras da região, tanto brasileiras como multinacionais.

\section{OS ATRIBUTOS ADSTRITOS E ADQUI- RIDOS NO RECRUTAMENTO DA ELITE EMPRESARIALPARANAENSE}

Os atributos adstritos funcionam como um primeiro filtro pelo qual os indivíduos passam, e funcionam mais no sentido de favorecer do que de determinar o acesso dos indivíduos às posições de elite. A análise dos dados indicam-nos alguns aspectos importantes. Em primeiro lugar, a elite empresarial paranaense é formada predominantemente por homens, brancos, católicos e com uma faixa etária média de 67 anos $^{7}$. Quanto ao local de nascimento, sete dos nove entrevistados nasceram

6 A FIEP desenvolve projetos como a Rede de Participação Política e "Vigilantes da democracia", que são inovadores na promoção da participação política em âmbito local e no acompanhamento da ação dos políticos eleitos, em âmbito estadual e nacional. Sobre essa experiência, ver Costa e França (2012).

7 Areligião é uma variável considerada um atributo adstrito por Suzanne Keller (1971) e corrobora a homogeneidade em termos desse tipo de atributo da elite empresarial paranaense. na cidade de Curitiba e apenas um entrevistado não nasceu no estado do Paraná.

Quando comparamos nossos entrevistados com a população paranaense ou mesmo com outras elites dentro desse estado, observamos algumas diferenças. Em relação ao sexo, a divisão da população paranaense é muito equilibrada havendo $50,47 \%$ de homens e $49,53 \%$ de mulheres. Já em nossa elite, ocorre a total ausência de mulheres. Outro ponto é em relação à raça. Apesar do estado do Paraná não ter uma taxa alta de negros $(2,84 \%)$ e pardos $(18,25 \%)$, nessa elite ocorre exclusivamente a presença de brancos ${ }^{8}$.

O grau de escolaridade dessa elite também é discrepante quando comparado ao restante da população do estado e também com as outras elites. Apenas $9 \%$ da população possui alta escolaridade, com $46 \%$ média escolaridade e $45 \%$ baixa escolaridade. Ao compararmos com as outras elites, a empresarial também é a mais escolarizada, pois a político-administrativa, composta pelos secretários de estado, tem $90,4 \%$ dos seus membros com alta escolaridade, a partidária, composta pelos presidentes dos partidos políticos, com $71,4 \%$ e a parlamentar, composta pelos deputados estaduais, com 59,4\%.

Quanto aos atributos adquiridos da elite empresarial paranaense, em primeiro lugar, a escolaridade indica um índice de educação altamente elevado. Todos os entrevistados possuem ensino superior completo, sendo que três possuem pós-graduação. Em relação à formação acadêmica, o curso de Engenharia consta da formação de quatro dos nove entrevistados, seguido por Direito, com dois, e Ciências Econômicas ou Ciências Contábeis, com três

\footnotetext{
8 Os dados populacionais foram retirados de IBGE (2011), censo de 2000. Em relação ao sexo e à raça, a elite empresarial paranaense aproxima-se muito da elite partidária paranaense, composta pelos presidentes dos partidos mais importantes na política estadual, dado que ambas caracterizam-se por serem exclusivamente composta por homens brancos, enquanto que em outras elites políticas do estado, como a parlamentar, composta pelos deputados estaduais, há ocorrências de mulheres (4,3\%). A presença feminina é ainda maior na elite políticoadministrativa, composta por aqueles que ocuparam cargos nas secretarias estaduais e em algumas empresas estatais, com $16,4 \%$. Os dados sobre as elites políticas paranaenses foram retirados das pesquisas realizadas no NUSP-UFPR e constam dos trabalhos apresentados em Perissinotto et alii (2007).
} 
entrevistados. Por último, no que diz respeito às instituições de ensino freqüentadas, a Universidade Federal do Paraná predomina com cinco entrevistados, sendo os demais distribuídos por instituições privadas. Quando relacionado ao nível de educação dos entrevistados em relação aos seus pais, percebemos que praticamente não houve mobilidade educacional, visto que apenas o pai de um deles não possuía grau universitário.

Já em relação à ocupação profissional, cabe ressaltar a diferença entre formação e diploma de ocupação real, pois as duas coisas podem não coincidir. Ao analisarmos a trajetória da elite empresarial paranaense a partir da ocupação real que os entrevistados exerceram por mais tempo antes de chegarem à presidência da entidade de representação em que se encontravam, os dados indicam que os dirigentes das instituições encontravam-se nas seguintes ocupações: diretor e executivo de empresa, com cinco entrevistados, seguidos de dois proprietários urbanos e dois profissionais liberais.

Considerando a natureza da elite aqui estudada, obviamente as ocupações de executivo de empresa e proprietário urbano aparecem como atributos mais do que fundamentais para chegar-se a posições de representação empresarial, mas podemos notar que a profissionalização é o dado mais relevante nesse processo, ou seja, poucos tinham a condição de ser exclusivamente proprietários.

Em relação à trajetória política, trata-se de um elemento fundamental do estudo sobre recrutamento, em particular em função da natureza política da elite empresarial, e permitenos descobrir se existe um caminho que favoreça o indivíduo a alcançar a posição de dirigente, ou seja, as experiências que contribuem positivamente para alcançar a posição de elite.

Entre os nove entrevistados, cinco ocuparam cargos públicos, em especial nas secretarias estaduais. Quanto ao pertencimento a partidos políticos, quatro foram filiados, três nunca pertenceram a partidos políticos e dois não responderam. Mas o mais relevante é que nenhum dos entrevistados atualmente pertence a algum partido político. Outro ponto a ser destacado é a participação dos dirigentes das entidades na direção de clubes e sociedades tradicionais de Curitiba. Dos entrevistados, cinco participaram ou participam da direção dessas instituições.
Por último, no que se refere à ocupação de cargos de direção de entidades de representação empresarial, todos os entrevistados ocuparam tais cargos em outras ou nas mesmas entidades em diretorias anteriores, ou como presidentes das instituições sindicais locais. Isso sugere que a trajetória dentro de setores de representação empresarial é importante na medida em que faz parte do recrutamento de postos de comando mais altos, como é o caso da presidência das entidades.

\section{A CULTURA POLÍTICA DA ELITE EMPRE- SARIALPARANAENSE}

Tratados os aspectos gerais sobre recrutamento e trajetória política, apresentaremos agora os dados sobre os valores políticos que a elite empresarial compartilha, especialmente aqueles relacionados aos seguintes temas: (i) concepção sobre os aspectos gerais da democracia; (ii) funcionamento e confiança nas instituições democráticas; (iii) consolidação da democracia no Brasil e (iv) a reforma política ${ }^{9}$.

Os dados sobre os aspectos gerais da democracia são interessantes para perceber o grau de coesão dessa elite. Os entrevistados foram perguntados sobre algumas características gerais do sistema democrático e em que medida essas características seriam importantes para o bom funcionamento da democracia.

A participação da população nos processos decisórios é vista pelos entrevistados como essencial e necessária à democracia. As justificativas foram as seguintes: a participação é um princípio democrático fundamental; é papel dos cidadãos acompanhar as ações dos governantes; a participação seria um meio de consolidar a democracia e as decisões mais importantes deveriam ser compartilhadas, ao máximo possível, por toda sociedade. As ressalvas que foram feitas referiam-se apenas à dificuldade de submeter todos os temas à discussão coletiva.

Outro ponto importante foi a adesão da população aos valores democráticos, vista como essencial e necessária, justificada pela idéia de que isso poderia levar a uma maior participação da população na vida política. Já em relação à competência administrativa por parte dos governos, também é vista como essencial e

9 Os resultados relativos aos valores políticos estão no Anexo 2. 
necessária. As justificativas basearam-se, por um lado, no entendimento de que a competência administrativa deve ser uma obrigação por parte dos governantes para com o bem público, e por outro, que a falta desse tipo de competência levaria a um enfraquecimento da democracia, acabando até por criar terreno para soluções não democráticas.

A importância do respeito às autoridades constituídas também é unânime e baseia-se na idéia de que se trata de um princípio hierárquico que mantém a ordem e faz a democracia funcionar. Contudo, houve a ressalva de que esse respeito só deveria ser mantido enquanto as autoridades constituídas forem dignas disso. Quando não merecessem mais tal respeito, elas devem ser destituídas, o que deveria ocorrer sempre dentro do devido processo legal.

Outro aspecto analisado foi a liberdade de mercado e de iniciativa. Esse item aparece como algo essencial e necessário à democracia, e os argumentos são de que se trata de um princípio fundamental da sociedade capitalista e que o Estado deveria cuidar apenas dos setores básicos, como saúde, educação e habitação. Mas, há a ressalva de que essa liberdade não deve ser ilimitada, mas estar sempre sobre o controle dos dispositivos legais.

Por último, questionou-se a importância do equilíbrio entre os poderes Executivo e Legislativo. As justificativas foram de que o equilíbrio seria essencial e necessário, já que evitaria possíveis crises políticas, mantendo assim a harmonia entre os poderes. A falta desse equilíbrio foi exemplificada pelo fato de o poder Executivo legislar cada vez mais, sendo que essa seria uma atribuição específica das instituições legislativas, o que comprometeria o bom funcionamento do sistema democrático.

A adesão à democracia por parte da elite empresarial situa-se em níveis muito altos. Quando perguntados se a democracia é a melhor forma de governo para solucionar crises, as respostas afirmativas foram unânimes. Apesar dos problemas que o sistema democrático possui, ele é considerado a melhor forma de governo possível. As justificativas foram de que a democracia permite a conciliação das partes por meio do entendimento e que os problemas políticos sempre tiveram saídas políticas.
Ainda em relação às instituições democráticas, confrontamos os entrevistados com a seguinte questão: se fosse necessário optar entre o bom funcionamento das instituições políticas ou o bom funcionamento das instituições econômicas, qual o senhor escolheria? As respostas na sua totalidade foram pelo bom funcionamento das instituições políticas, justificadas pelo fato de que o bom funcionamento das instituições políticas é o prérequisito para a estabilidade e o bom funcionamento das instituições econômicas. Houve, por parte, de um entrevistado a afirmação de que, em uma eventual situação que envolveria escolher entre o bom funcionamento das instituições econômicas ou políticas, o bom funcionamento apenas das instituições econômicas poderia funcionar como uma porta que levaria a um estado autoritário, no qual poderiam ser garantidas as condições econômicas para a população, mas suprimidas as suas liberdades individuais e políticas.

Quanto à possibilidade de uma reforma nas instituições políticas representativas e disso mudar a forma como o governo toma as decisões econômicas, os entrevistados mostraram-se bastante confiantes ${ }^{10}$. A reforma política foi vista como extremamente necessária. Segundo os empresários, essa mudança poderia facilitar a cobrança sobre os eleitos, bem como contribuir na solução de erros, levando assim a um maior aperfeiçoamento das instituições.

Quando perguntados se a democracia brasileira estaria consolidada e, por isso, pouco sujeita a crises que poderiam levar ao seu abandono, as respostas dos empresários foram de que a democracia brasileira está sim consolidada e que há problemas pontuais relacionados à qualidade dos representantes, mas as justificativas foram que a sociedade em geral está atenta aos rumos do país e que nem o quadro institucional interno

10 A reforma política, embora não tenha se efetivado, está sempre presente no horizonte do cenário político nacional. Portanto, deve ser tomada não apenas como elemento para avaliação da coesão no âmbito dos valores políticos, mas também como elemento constitutivo de uma eventual ação política, embora tenhamos verificado que poucos entrevistados declararam que suas entidades possuíam ações no intuito de aperfeiçoar as instituições democráticas. 
e nem o cenário mundial permitiriam mudanças autoritárias nos rumos da democracia brasileira.

Feitas as considerações sobre alguns aspectos gerais da concepção de democracia, verificaremos agora questões relativas ao grau de confiança do empresariado frente às instituições democráticas. Embora tal questão remeta à vasta literatura sobre instituições políticas, observa-se que pouco tem sido verificado em relação à posição dos grupos sociais específicos frente a elas. Nesse sentido, são dois os pressupostos que regem essa parte da pesquisa: o primeiro é a cultura política, no que diz respeito à confiança e sua relação com a consolidação e a estabilidade do regime democrático. O segundo é a cultura política, entendida como um fator que diminuiria a incerteza provocada pelos riscos da ação coletiva, o que sem dúvida é interessante quando se estuda um grupo com ações articuladas constantes (ALMOND \& VERBA, 1989; PUTNAM, 2002).

Quanto ao grau de confiança da elite empresarial paranaense em relação às instituições políticas do poder Executivo, a Presidência da República recebeu avaliações entre confiável e pouco confiável e as justificativas foram de que a economia brasileira vai bem, mas que há um desequilíbrio entre os setores da economia, uns recebendo mais atenção por parte do poder Executivo federal do que outros. O governo do estado foi mal avaliado por quase a totalidade dos entrevistados. As justificativas foram de que a sua atuação não foi satisfatória e, em certo sentido, até mesmo de caráter "populista", embora um entrevistado tenha uma avaliação positiva, argumentando que o governo do estado teria se mostrado um parceiro do empresariado. Por último, as respostas indicam a satisfação com o poder Executivo municipal, no sentido de que Curitiba teria um histórico de bons prefeitos, que as demandas continuavam sendo atendidas e que a prefeitura estaria atuando com seriedade e tomando boas decisões.

No que tange às instituições jurídicas (poder Judiciário federal e estadual, Ministério Público federal e estadual), foram bem avaliadas pela quase totalidade dos entrevistados. As justificativas foram de que as instituições estão cumprindo seus objetivos, mas alguns entrevistados informaram que não possuem conhecimentos suficientes sobre essas instituições. As ressalvas a essa avaliação foram de que as instituições jurídicas são pouco efetivas e que freqüentemente aplicam sentenças equivocadas.

Por sua vez, as instituições do poder Legislativo não partilharam da mesma avaliação positiva que as instituições do poder Executivo e do poder Judiciário. O Senado Federal e a Câmara Federal foram avaliados como pouco confiáveis ou, no máximo, confiáveis. As justificativas foram de que o Senado Federal e a Câmara Federal estão partidarizados e que as decisões são tomadas mais em função dos objetivos individuais e partidários do que em função das necessidades da nação, e que o legislativo federal possui pouca efetividade no cenário político. Há também uma avaliação negativa em relação à qualidade dos políticos e, conseqüentemente, da representação política. Ainda em relação às instituições legislativas, a Assembléia Legislativa recebeu uma avaliação dispersa, mas predominantemente negativa. As justificativas dos entrevistados deram-se em função da instituição possuir inúmeros problemas internos e não ter uma boa atuação.

Quanto ao grau de confiança nos partidos políticos, as avaliações dos entrevistados foram dispersas, mas predominantemente negativas. As justificativas foram de que, em sua maioria, os partidos possuem plataformas muito vagas, não possuem estrutura e geralmente as alianças entre os partidos são incoerentes com as suas propostas originais. Por último, em relação às próprias entidades de representação empresarial, foram avaliadas com um alto grau de confiança.

Como vimos anteriormente, a maneira como os indivíduos avaliam o desempenho das instituições acaba por influenciar diretamente o grau de confiança ou desconfiança nessas mesmas instituições. Veremos, agora, a avaliação do empresariado frente ao desempenho das seguintes instituições: Presidência da República, governo do estado, Banco do Brasil, Banco Nacional do Desenvolvimento (Bndes), Banco Central, sistema partidário e sistema eleitoral.

Com relação à Presidência da República, seu desempenho foi predominantemente considerado como satisfatório. Os entrevistados avaliaram a presidência a partir de seu desempenho econômico, que, apesar de positivo, teria sido fruto de ações de governos anteriores. Embora a presidência tenha sido criticada por que teria se aproveitado de propagandas de programas assistenciais como meio de obter popularidade, 
assim confundido a população e deixando projetos nacionais de lado, ela foi bem avaliada no sentido de ter sido uma administração acima da média. Já o desempenho do governo do estado foi avaliado quase na sua totalidade como ruim. As justificativas foram de que o governo foi também populista e com uma administração letárgica.

Sobre as instituições econômicas, o Banco do Brasil teve seu desempenho avaliado entre bom e satisfatório e é visto como um banco parceiro nas demandas empresariais, muito fortalecido pela política financeira brasileira. O Bndes foi avaliado de maneira relativamente positiva e foi defendido por ser a única agência de fomento do Brasil. Houve, entretanto, críticas quanto ao fato de o banco favorecer determinados setores em detrimento de outros. O Banco Central é bem avaliado pelo fato de desempenhar bem o seu papel de controle da inflação, mesmo que a partir da manipulação dos juros altos.

O funcionamento do sistema partidário e do sistema eleitoral recebeu avaliações dispersas, mas que ficaram entre satisfatório e ruim. As críticas foram de que os partidos políticos não possuem nenhum tipo de ideário e que estão mais preocupados com seus ganhos do que com o Estado como um todo. Houve uma avaliação positiva em relação ao aspecto operacional do sistema eleitoral, como um processo bom, seguro, rápido e eficiente. A insatisfação em relação ao sistema eleitoral por parte dos entrevistados foi seguida pela indicação da necessidade de uma reforma política, sugerindo, por exemplo, a adoção do sistema distrital.

Perguntados sobre a reforma política, os entrevistados mostraram-se coesos com relação aos temas fundamentais que permeiam o debate, como voto obrigatório, financiamento público de campanhas, constituinte exclusiva, entre outros. A seguir, trataremos dos pontos levantados, bem como das justificativas das posições tomadas.

Com relação ao financiamento público de campanha, a maioria dos entrevistados mostrouse a favor e as justificativas foram de que isso poderia dar mais transparência aos partidos políticos. As duas avaliações que se posicionaram contra afirmaram que já existe, por exemplo, o horário gratuito de campanha, e que os partidos devem buscar doações a partir da mobilização do seu eleitorado e não nos cofres públicos.
No que tange ao debate sobre voto distrital, os entrevistados, na sua totalidade, mostraramse a favor, e as justificativas indicam que o voto distrital poderia levar a uma maior responsividade e representatividade por parte dos eleitos. A fidelidade partidária é vista por todos os entrevistados como uma obrigação, por parte dos candidatos, em relação aos partidos. Os entrevistados também entendem que o fim da reeleição para cargos do poder Executivo é necessário, argumentando que os segundos mandatos são sempre ruins. Os entrevistados também são, em sua totalidade, a favor do fim do voto obrigatório. As justificativas foram de que o Brasil está preparado e sua democracia consolidada, e por isso o voto deve ser livre, caso contrário, a obrigação tiraria a liberdade dos indivíduos. Por último, quanto à necessidade de uma constituinte exclusiva para votar a reforma política, os entrevistados mostraram-se a favor. A justificativa foi que, atualmente, nem a oposição, nem a situação desejam fazer a reforma política.

\section{OS PADRÕES DE AÇÃO POLÍTICA DA \\ ELITE EMPRESARIAL PARANAENSE}

Quanto às formas de representação empresarial, os resultados podem ser encontrados no Anexo 3. Perguntamos aos entrevistados se haveria a necessidade de uma entidade que representasse o conjunto dos interesses de todo os setores do empresariado brasileiro frente ao governo e à sociedade. As posições dividiram-se. $\mathrm{O}$ argumento dos favoráveis refere-se à integração entre os setores diferentes, o que daria mais força ao empresariado brasileiro; já os contrários, acreditam que, diante da multiplicidade de interesses, a representação única não seria interessante. Todos os entrevistados concordam que há necessidade de o empresariado formular um projeto seu para o Estado e a sociedade brasileiros, o que indica a importância a que eles se atribuem nesse projeto envolvendo o Estado e o desenvolvimento econômico.

Em relação aos padrões de ação política, averiguamos os aspectos gerais das estratégias das entidades na defesa de seus interesses frente ao conjunto do empresariado e ao Estado. Em primeiro lugar, a grande maioria dos entrevistados declarou que as ações davam-se de maneira articulada com outras entidades. Os entrevistados afirmaram que o lobby é mais eficaz que o financiamento de campanha na defesa dos 
interesses da entidade. Já no que se refere às ações que as entidades adotariam em relação às eleições de 2010, a maioria dos entrevistados afirmou que se preocuparia prioritariamente com os candidatos a cargos do poder Executivo.

Perguntamos também como se dariam as relações da sua entidade com algumas instituições estatais, levando em conta as formas de contatos, o grau de sucesso e os principais assuntos tratados. Verificamos que praticamente todas as entidades têm ação intensa no poder Executivo estadual e avaliam tal ação como bem sucedida, utilizando todos os canais disponíveis, predominando os contatos pessoais. Já em relação ao poder Legislativo estadual, a avaliação praticamente inverte-se, mas também predominam os contatos de natureza pessoal.

Já no que se refere ao âmbito nacional, há também uma intensa relação com o poder Executivo, seja com o Presidente da República, seja com o seu Vice, com o Ministro da Fazenda ou ministros mais próximos politicamente, como foi o caso de Paulo Bernardo da pasta do Planejamento, além de outros órgãos do Governo Federal. Os temas geralmente estão relacionados com a defesa do setor que a entidade representa, em especial projetos de lei contrários ao segmento empresarial representado. Em relação ao Banco do Brasil e ao Bndes, poucas entidades atuam, mas, as que o fazem, julgam suas ações como bem sucedidas. Os temas tratados, o que não poderia deixar de ser, são especificamente econômicos, predominantemente relacionados ao financiamento dos setores representados.

Em relação ao poder Legislativo federal, praticamente todos possuem algum tipo de relação, tanto no Senado Federal quanto na Câmara dos Deputados, e os contatos são mais formais, embora poucas entidades realizem essa atividade freqüentemente, já que essas relações dão-se por meio de entidades nacionais. Quanto às formas de contato, geralmente dão-se por meio da bancada paranaense na Câmara e no Senado e do que se definiu como frente parlamentar da micro-empresa no Congresso Nacional.

\section{ANÁLISE DOS DADOS}

Considerando os resultados obtidos, em primeiro lugar, aqueles relacionados ao recrutamento, podemos dizer que a homogeneidade da elite empresarial paranaense em relação aos seus atributos adstritos e adquiridos mais do que comprova a diferenciação em relação à população brasileira ou paranaense, e, também, indica um padrão de recrutamento fechado e localista, ou seja, concentrado na cidade de Curitiba. Se fizermos uma comparação com os resultados de pesquisas anteriores, percebemos que entre os anos de 1995 a 2005 (COSTA \& ENGLER, 2008) e os anos de 2010 e 2011, a elite empresarial paranaense mostrou-se altamente homogênea, o que sugere que praticamente não houve mudanças quanto ao padrão de recrutamento mantido ao longo desses quase 15 anos contemplados pelas duas pesquisas.

Em suma, os atributos adstritos e adquiridos sugerem menos que a sua posse torna o acesso à elite empresarial mais fácil, e mais uma semelhança no que tange as experiências de vida. Tal semelhança sugere que os processos de ascensão aos cargos, que sempre passam pela disputa eleitoral, favorecem os indivíduos que possuem tais características, dada a sua inequívoca predominância. Mas, verificamos que, embora a homogeneidade social seja importante, está longe de ser suficiente, ou seja, ela é parte de um conjunto de semelhanças.

Daí a importância da questão da trajetória. Os dados indicam que a elite empresarial paranaense pouco ocupou cargos públicos ou partidários. Em contrapartida, observamos um alto grau de participação em entidades de representação empresarial. O que ocorre aqui é o afastamento da atividade política pública e uma grande experiência anterior em entidades sociais, uma especialização ou quase profissionalização na ocupação de cargos de direção desse tipo de entidade. Assim, ao lado da homogeneidade ou das semelhanças em relação aos atributos adstritos e adquiridos, as vias de acesso tendem a favorecer aqueles que tiveram experiências anteriores de direção de entidades, em especial as propriamente empresariais, sendo, portanto, mais relevantes do que a experiência em cargos públicos. Esse é um dado que reforça a constatação de que houve poucas mudanças quanto à trajetória da elite empresarial paranaense. Para isso, basta compararmos novamente os dados obtidos aqui com aqueles que já indicavam uma predominância do distanciamento dos cargos políticos e uma maior ocupação de cargos de direção de entidades empresariais, em especial o de presidente (idem). 
Ao compararmos a elite empresarial tratada neste trabalho com o estudo realizado por Pohlmann et alii (2010) sobre o caso alemão, algumas observações podem ser feitas. Embora tal estudo trabalhe com o conceito de "elite econômica", considerada a partir do critério da ocupação dos postos principais em grandes empresas industriais, indica que uma grande parte dos empresários é recrutada nas altas camadas sociais, tendo uma origem social comum, além de ter uma trajetória familiar ligada à atividade empresarial. Entretanto, tal estudo constata também que, apesar do recrutamento socialmente fechado, há um peso muito maior da trajetória e da carreira, sendo esses os atributos mais importantes para ingressar naquela elite. Também verificou-se que a educação é uma característica muito importante, e com destaque para os cursos superiores de Ciências Econômicas e Engenharias, também evidenciados por nossas pesquisas.

Em suma, a trajetória dos entrevistados indica que, embora haja homogeneidade em relação aos atributos adstritos e adquiridos, a elite empresarial paranaense caracteriza-se por uma alta capacidade política e uma especialização, seja ela relacionada à experiência na obtenção dos votos dos filiados, seja na própria gestão e administração desse tipo de entidade. Por fim, essa experiência pode ser verificada por meio do período em que os entrevistados estiveram à frente de entidades de representação empresarial, que é, em média, de $24 \operatorname{anos}^{11}$.

Quando consideramos os valores políticos, verificamos que a elite aqui estudada possui um alto grau de coesão, expresso em aspectos como a grande adesão à democracia, a consideração de que a participação popular é um princípio cívico e também em relação à consolidação da democracia no Brasil.

Em relação a esses aspectos, em primeiro lugar, pudemos perceber que há uma correspondência entre as avaliações sobre a democracia e sobre as instituições, de um lado, e o grau de satisfação e os padrões de ação política da elite empresarial paranaense, de outro. Voltaremos a esse ponto mais adiante. Em segundo lugar, as justificativas mostraram que, no momento da avaliação e da expressão das

11 Houve casos de presidentes que possuíam mais de 35 anos à frente de entidades de representação empresarial. opiniões, os respondentes tendem a ser mais rigorosos do que de fato o são no dia a dia das relações com os valores e instituições avaliados, o que nos mostra que a insatisfação muitas vezes expressa não é o que de fato guia a conduta concreta dos agentes, mas sim os seus projetos e desejos, tanto que isso não os leva a uma ação efetiva, seja de afastamento e crítica, seja de mobilização e esforço, para o aperfeiçoamento das instituições, estas como concretização e expressão de valores e metas políticas.

Isso reforça a constatação que fizemos na dimensão nacional dessa mesma pesquisa (COSTA, 2012), ou seja, em relação à elite empresarial paranaense também não se dá a "situação paradoxal" apontada por Moisés e Carneiro (2010) e Meneguello (2010), considerando a população brasileira em geral, entre, de um lado, a crescente adesão à democracia e, de outro, a alta taxa de descontentamento e a insatisfação com as instituições democráticas. Essa elite, assim como seus pares em âmbito nacional, possui total adesão à democracia e um relativo grau de satisfação com as instituições democráticas e, em função disso, tende a não atuar no sentido de promover alterações nos aspectos institucionais da democracia brasileira. E o que merece destaque é o fato de que verificamos que, também no âmbito mais propriamente local, no caso, estadual, essa relação favorável dá-se tanto com a democracia quanto com suas instituições.

Vimos acima os aspectos que indicam essa tendência à coesão, embora isso não possa ser tomado como consenso, nem permite desconsiderar a importância sociológica das eventuais divergências. Enfim, a idéia de coesão não remete a consenso, seja em relação a aspectos da cultura política, seja em relação ao desempenho das instituições e da questão do seu aperfeiçoamento, no caso, a reforma política. Em relação a isso, dois pontos chamam a atenção pelo fato de mostrarem uma diferença entre as posições da elite empresarial paranaense em relação à nacional. De um lado, a reeleição para cargos do poder Executivo, que é avaliada positivamente no âmbito nacional, favorável à manutenção da reeleição para os cargos desse mesmo poder (COSTA, 2012). Não há elementos para concluirmos, mas talvez isso se deva ao fato de que, na opinião da elite empresarial, o desempenho dos presidentes da república tem sido mais satisfatório do que aquele dos governadores, 
em particular no Paraná, o que os levaria a uma avaliação negativa da reeleição no âmbito estadual. $\mathrm{E}$, de outro, a constituinte exclusiva para a reforma política, que, inversamente, é vista nesse âmbito como desnecessária pela elite empresarial nacional.

Quanto à questão da confiança, no que tange às instituições representativas, os partidos e as casas do poder Legislativo são mais mal avaliados do que aquelas do poder Executivo. Ou seja, as instituições ligadas ao dia a dia da administração da coisa pública e da implementação das políticas possui uma avaliação mais positiva do que aquelas, por excelência, de representação ${ }^{12}$. Assim, há indícios que a insatisfação dá-se mais em relação ao processo de representação do que de gestão da coisa pública.

Sobre esse ponto, nossos dados indicam outra diferença em relação ao que Moisés e Carneiro (2010) verificaram em relação à população brasileira. Em primeiro lugar, a elite empresarial possui maior capacidade de distinguir aquilo que Easton (2005) chama de apoio difuso e apoio específico, ou seja, maior capacidade de distinguir as instituições dos que, em um dado momento, ocupam-nas. Em segundo lugar, e correlatamente a esse primeiro aspecto, não há sinais de que os membros dessa elite desejariam ou pensariam a possibilidade de uma democracia no Congresso Nacional ou nos partidos políticos.

Em relação ao alto grau de confiança entre as próprias entidades de representação empresarial, comparado com o que ocorre em relação a outras instituições, por exemplo, os partidos políticos, devemos considerar que estamos tratando de um grupo limitado, formado por um processo de socialização e trajetórias semelhantes e que, dentro das suas atribuições de dirigentes de entidades de representação, ao menos declaram que possuem ações articuladas entre si, o que exige e fomenta a confiança mútua. Não se trata de desconsiderar as divergências e disputas que podem ocorrer entre os setores do empresariado pela definição das políticas públicas, mas sim da existência de uma atitude favorável à confiança, à ação conjunta e à busca da concertação.

12 Já em $O$ dezoito brumário de Luís Bonaparte, Marx (s/d) chamava a atenção para o fato de o poder Legislativo estar em relação metafísica com a sociedade, enquanto o poder Executivo estava em relação direta com ela.
E os dados sobre a avaliação do desempenho das instituições e da questão da reforma política indicam também, além da coesão, uma preocupação com a qualidade da democracia. Isso é bastante relevante quando se considera a importância dos laços entre a democracia e os grupos sociais, no âmbito mais local e próximo das atividades e da vida dos indivíduos que os compõem. Em suma, verificamos que não apenas as semelhanças em relação, de um lado, aos atributos adstritos e adquiridos e, de outro, de trajetória política, como também as semelhanças em relação às atitudes e valores políticos são importantes nas vias de acesso à elite aqui estudada.

Os valores políticos da elite empresarial paranaense permitem-nos as seguintes conclusões: (i) quanto à aceitação do princípio da participação, a democracia não se restringiria à representação; (ii) a alta adesão aos valores democráticos, por um lado, vem acompanhada, de outro, do posicionamento de que a adesão aos valores democráticos por parte da população em geral é uma condição para o funcionamento e o sucesso da democracia; (iii) a democracia seria o melhor caminho político para solucionar as crises e os problemas, políticos ou não; (iv) o desempenho administrativo dos governantes é justificado menos por uma visão pragmática ou gerencialista de política e mais como uma condição para o sucesso da democracia ${ }^{13}$; $(v)$ o respeito às autoridades, assim como na questão da competência administrativa dos governantes, possuem um teor republicano, ou seja, o princípio fundamental é o do controle dos governantes pelos governados, sempre fundado em regras estabelecidas; (vi) se há uma visão liberal em relação à liberdade de mercado, ela é bastante liberal em relação à adesão aos valores políticos liberais no que diz respeito à adesão à democracia, como é observado na primazia atribuída às instituições políticas frente às econômicas. Isso que nos permite considerar que há uma maior inclinação a aspectos relacionados às liberdades e igualdades políticas do que simplesmente à

13 Esse aspecto é importante, pois em outras pesquisas relativas à década de 1990 , verificamos que tal visão gerencialista, ou seja, a política como algo que dizia respeito à boa capacidade de administrar recursos e pessoas, era presente entre os representantes do empresariado (COSTA, 2005; 2008). 
igualdade e à liberdade no sentido estritamente econômico, no âmbito do mercado. Essa constatação é reforçada pela importância que se dá à reforma política e à confiança na consolidação da democracia no país.

Quando consideramos os padrões de ação política indicados pelos entrevistados, em primeiro lugar, podemos acrescentar outro aspecto de natureza teórica e metodológica da nossa pesquisa, ou seja, a tentativa de articular a análise de aspectos relacionados ao recrutamento, às características dos membros e aos valores políticos de uma dada elite, com a sua ação concreta nas instituições que eles dirigem. Isso permite agregar, ao método posicional, a consideração das consequiências da ocupação dos cargos sobre o funcionamento e a ação da instituição na qual tais cargos estão inseridos, ou seja, a ação da elite é considerada, e considerada como ação de uma instituição, e não de um indivíduo.

Em segundo lugar, os dados indicam que a ação política tende a ser mais intensa no poder Executivo federal, que, por sua vez, é muito bem avaliado e recebe um alto grau de confiança, bem como tem seu desempenho avaliado entre bom e satisfatório. O poder Legislativo, independente do nível, não foi bem avaliado, mas associado a problemas, e foi muito pouco procurado na ação das entidades. Isso é corroborado pela maior preocupação com os cargos do poder Executivo nas eleições de 2010. Tais aspectos indicam uma correlação entre cultura política e ação por parte dessa elite. Isso reforça a importância dos estudos dos valores políticos, não como variáveis independentes, mas como componentes de uma metodologia de análise da ação.

Nesse sentido, mesmo sem a pretensão de avaliar ou indicar coerências e incoerências no comportamento político, verificamos que, embora haja a declaração de que a ação conjunta é preferível, no dia a dia as ações isoladas predominam. Isso pode ser observado também em relação à proposta de uma entidade que representasse o conjunto dos interesses dos empresários, pois, ainda que haja uma divisão das posições em relação à necessidade deste tipo de entidade, não há necessariamente uma ação contundente no sentido de fortalecer, consolidar e institucionalizar o "G8", grupo de entidades de representação empresarial acima mencionado, e que teria exatamente esse papel de fortalecimento das ações conjuntas, dado que tal grupo atua de modo esporádico e pontual.

$\mathrm{O}$ fato de que o entendimento, por parte dos entrevistados, de que seria necessário um projeto do conjunto do empresariado frente ao Estado e à sociedade, convive com a ausência de ações concretas nesse sentido, indica, de um lado, que as entidades estão mais voltadas para o dia a dia da representação dos interesses de seus filiados, ficando as questões de longo prazo em segundo plano na agenda de ações das entidades, mas de outro, que o grau de insatisfação não é alto nem suficiente para levá-los à mobilização pela reforma das instituições políticas.

Quanto às relações com as instituições do Estado, em primeiro lugar, estamos analisando entidades de representação empresarial de nível regional, portanto, mais próximas dos centros de decisões estaduais, o que favorece a predominância dos contatos pessoais. Em segundo lugar, assim como indicam as declarações sobre a ação que as entidades pretendiam desenvolver nas eleições de 2010, observamos a predominância do poder Executivo, nos níveis estadual e nacional, na agenda de ações das entidades, evidenciado também pelo fato de que a ação relativa aos projetos de lei volta-se mais para o poder Executivo do que para o próprio poder Legislativo.

O que mais se destaca são as declarações de que as ações, de um modo geral, têm sido bem sucedidas. Como vimos acima, isso indica certo grau de satisfação dessa elite com o funcionamento de tais instituições, portanto, com a institucionalização da democracia no Brasil, em âmbito nacional e, em especial, estadual. Entretanto, entendemos que isso deve ser entendido menos como uma alta responsividade do Estado em relação aos interesses do empresariado, e mais como um amadurecimento de seus representantes em relação ao que se pode esperar do processo decisório nas democracias, ou seja, que se trata de um processo complexo de articulação de interesses no qual o atendimento pleno das demandas não pode ser o critério absoluto para uma avaliação positiva das instituições. Enfim, a elite empresarial está mais satisfeita menos porque suas preferências estão sendo consideradas pelos governantes e mais porque parece estar mais consciente, em comparação com as "massas", dos limites e 
das vicissitudes da democracia, ou seja, que o atendimento das demandas está sujeito aos complexos processos políticos típicos da democracia.

Constatamos que há uma homogeneidade entre as entidades, independentemente da sua natureza e do setor representado, em relação aos padrões de ação política por ela adotadas. Conforme constatado anteriormente (COSTA, 2005a), as entidades aqui contempladas costumam adotar as mesmas estratégias para defender seus interesses e, além disso, possuem uma avaliação semelhante em relação aos resultados de suas ações.

Outro ponto que merece destaque em nossa pesquisa reside também na utilização do lobby por parte de todas das entidades empresariais paranaenses pesquisadas, no processo de defesa de seus interesses. Esses dados corroboram a tese de Aragão (1994), que previa uma maior participação e institucionalização dos grupos de pressão no Brasil após a Constituinte de 1988. Os padrões de ação política e o amplo consenso sobre a legitimidade do lobby por parte das entidades consideradas sugerem também certa semelhança em relação aos grupos de interesse norte-americanos (cf. MANCUSO, 2007).

Por fim, a temática das articulações com os órgãos do Estado gira quase exclusivamente em torno dos interesses imediatos das entidades, ficando de fora as questões relacionadas a processos de longo prazo que ultrapassem o cotidiano das atividades empresariais, como, por exemplo, a reforma política. Em relação a este aspecto, a iniciativa da Rede de Participação Política, criada e sustentada pela FIEP e pela Faciap é uma exceção que confirma a regra (cf. COSTA \& FRANÇA, 2012; REDE EMPRESARIAL, 2012).

Enfim, a análise dos valores e dos padrões de ação política dessa elite empresarial indica que ela tende a constituir-se como uma importante base social da democracia nos dias de hoje, o que não é irrelevante, dada a participação dos empresários na sustentação de regimes políticos autoritários na história brasileira recente. E, como foi dito acima, isso é também relevante pelo fato de dizer respeito a um âmbito mais local do funcionamento da democracia brasileira. A idéia de que os padrões de ação política em relação aos poderes Executivo e Legislativo decorreriam das diferenças de importância desses poderes no processo decisório, não permite desconsiderar que a ação das entidades empresariais não tende e nem pretende alterar, mas, ao contrário, reforça um aspecto institucional da democracia brasileira, ou seja, o desequilíbrio entre os poderes Legislativo e Executivo.

Embora esse importante papel na sustentação da democracia brasileira não tenha tendido a desembocar em ações firmes e concretas quanto ao aperfeiçoamento das suas instituições políticas (a reforma política), restringindo-se ao processo cotidiano de articulação com as autoridades e órgãos governamentais para articular interesses específicos e de curto prazo, nosso estudo mostrou que isso se deve, ao menos parcialmente, ao grau de satisfação do empresariado com o funcionamento das instituições democráticas e à avaliação positiva das ações junto a essas instituições.

Portanto, por meio dos dados apresentados, podemos verificar uma homogeneidade por parte do empresariado paranaense em relação à forma como eles agem e aos caminhos utilizados para a consecução de seus objetivos na arena decisória, ou seja, em relação ao seu padrão de ação política. Normalmente são utilizados contatos pessoais, reuniões, audiências e o lobby para atingir seus objetivos. Por situarem-se em uma esfera regional, o contato do empresariado paranaense é normalmente direcionado aos tomadores de decisão locais (em maior incidência, o poder Executivo estadual), deixando para as confederações (caso a natureza da entidade seja sindical) ou às entidades superiores a discussão de temas e o exercício de pressão, no que se refere a questões nacionais e que envolvem o Governo Federal. Em relação aos assuntos abordados, estão geralmente em pauta questões regionais relacionadas ao setor e ao mercado como um todo e que podem influenciar diretamente a atuação dos representados por esse grupo. Além disso, os pleitos normalmente reivindicados são, em sua grande maioria, avaliados como bem sucedidos, o que indica certa semelhança também em relação à responsividade na relação com o governo.

\section{CONCLUSÕES}

As implicações teóricas e metodológicas de nossa pesquisa foram tratadas em outros trabalhos (COSTA \& ENGLER 2008; COSTA 2012). A 
contribuição teórica deu-se no sentido de articular, no estudo do empresariado, um grupo de variáveis relacionadas a três dimensões, recrutamento, cultura política e padrões de ação política, desse que é um ator fundamental para o desenvolvimento e as perspectivas da democracia no Brasil, e que está aqui sendo considerado menos como um agente econômico, mas, sobretudo politicamente relevante. Isso não significa, entretanto, que deixamos de lado atributos como poder ou representação de interesses de natureza econômica, o que seria um tanto quanto contraditório, já que estamos falando de um grupo que possui ou controla os meios de produção, o capital. Nossa análise buscou contribuir para a compreensão da formação e do comportamento dos indivíduos que são membros da elite empresarial e por isso, atores políticos que assumem a direção de entidades de representação política na sua relação com o funcionamento concreto das instituições políticas, remetendo a uma Sociologia Política da democracia no Brasil (COSTA, 2005a; 2005b; 2007; 2012; COSTA \& ENGLER, 2008).

O segundo ponto a ser destacado é o que difere nosso trabalho da maioria dos estudos correlatos, ou seja, a consideração da dimensão qualitativa das respostas. As justificativas das avaliações e posicionamentos permitem abordar as motivações subjetivas dos entrevistados, dando maior riqueza de detalhes a respeito das atitudes e comportamentos verificados, o que possibilita chegar mais perto dos motivos de seus posicionamentos e ações.

Em terceiro lugar, o entendimento de como o empresariado relaciona-se com estrutura governamental contribui não só para a compreensão do processo de formulação de políticas públicas, como, também, permite o entendimento do processo de interação entre a sociedade organizada e o setor público, na busca da representação dos interesses sociais na forma de grupos de pressão.

Por último, os resultados permitem também algumas especulações com importantes implicações teóricas, a serem desenvolvidas em estudos posteriores. De um lado, a consideração da elite como representante não apenas no sentido formal da ocupação dos cargos de representantes, mas como uma manifestação ou uma projeção do coletivo que está sendo representado. De um lado, a elite como representante não apenas no sentido formal da ocupação dos cargos de representantes, mas enquanto uma manifestação ou uma projeção do coletivo que está sendo representado, e de outro, permitindo especular sobre a questão da classe social subjacente a esta elite, menos no sentido de ser uma amostra fidedigna do coletivo, mas sim das suas contraditórias, complexas e efetivas formas de expressão e ação.. Correlatamente, isso nos leva à consideração do estudo de uma elite como forma de analisar a classe ou grupo social específico do qual essa elite decorre.

Paulo Roberto Neves Costa (paulocostaufpr@gmail.com) é Doutor em Ciências Sociais pela Universidade Estadual de Campinas (Unicamp) e Professor de Ciência Política na Universidade Federal do Paraná (UFPR).

Tiago Junior Roks (tiagoroks@ yahoo.com.br) é Graduado em Ciências Sociais pela Universidade Federal do Paraná (UFPR).

Guatimozin de Oliveira Santos Filho (guatimozin.filho@amchambrasil.com.br)é Mestrando em Ciência Política pela Universidade Federal do Paraná (UFPR).

\section{REFERÊNCIAS BIBLIOGRÁFICAS}

ALMON D, G. \& VERBA, S. 1989. The Civic Culture. Political Attitudes and Democracy in Five Nations. California: Sage.

ARAGÃO, M. 1994. Grupos de pressão no Congresso Nacional. São Paulo: Maltese.

CASTRO, D. \& VASCONCELOS, J. R. 1999.

Paraná: economia, finanças públicas e investimentos nos anos 90. Texto para Discussão n. 62. Brasília: Instituto de Pesquisa Econômica Aplicada. Disponível em: http:// www.ipea.gov.br/pub/td/td_99/td_624.pdf. Acesso em: 20.nov.2012.

COSTA, P. R. N. 2005a. Empresariado, regime político e democracia: Brasil, anos de 1990. 
Revista Brasileira de Ciências Sociais, São Paulo, v. 20, n. 57, p. 109-126, fev. Disponível em: http://www.scielo.br/pdf/rbcsoc/v20n57/ a07v2057.pdf. Acesso em: 19.nov.2012.

2005b. Como os empresários pensam a política e a democracia. Opinião Pública, Campinas, v. 11, n. 2, p. 422-449, out. Disponível em: http://www.scielo.br/pdf/op/ v11n2/26421.pdf. Acesso em: 19.nov.2012.

. 2007. Empresariado, instituições democráticas e reforma política. Revista de Sociologia e Política, Curitiba, n. 28, p. 99-116, jun. Disponível em: http://www.scielo.br/pdf/ rsocp/n28/a07n28.pdf. Acesso em: 19.nov.2012.

2012. A elite empresarial e as instituições democráticas: cultura política, confiança e padrões de ação política. Opinião Pública, São Paulo, v. 18, n. 2, p. 23-49, nov.

COSTA, P. R. N. \& ENGLER, I. J. F. 2008. Elite empresarial: recrutamento e valores políticos (Paraná, 1995-2005). Opinião Pública, Campinas, v. 14 , n. 2, p. 486-514, nov.-dez. Disponível em: http://www.scielo.br/pdf/op/ v14n2/09.pdf. Acesso em: 19.nov.2012.

COSTA, P. R. N. \& FRANÇA, A. S. T. 2012. Da responsabilidade social à responsabilidade política: uma análise da Rede de Participação Política. In: COSTA, A. J. D.; MINELLA, A. C.; IGLECIAS, W.; ETCHEVERRY, M. S.; GROS, D. B. \& MICK, J. (orgs.). Estado, empresas e empresários: agentes de desenvolvimento. Curitiba: CRV.

EASTON, D. 1965. A System Analysis of Political Life. New York: Wiley.

KELLER, S. 1971. Más allá de la clase dirigente. Madrid: Tecnos.

MANCUSO, W. P. 2007. O empresariado como ator político no Brasil: balanço da literatura e agenda de pesquisa. Revista de Sociologia e Política, Curitiba, n. 28, p. 131-146, jun. Disponível em: http://www.scielo.br/pdf/rsocp/ n28/a09n28.pdf. Acesso em: 4.dez.2012.

MARX, K. s/d. O dezoito brumário de Luís Bonaparte. In: MARX, K. \& ENGELS, F. Obras escolhidas. V. 1. São Paulo: Alfa-Ômega.

MENEGUELLO，R. 2010. Aspectos do desempenho democrático: estudo sobre a adesão à democracia e avaliação do regime. In: MOISÉS, J. A. (org.). Democracia e confiança: por que os cidadãos comuns desconfiam das instituições. São Paulo: USP.

MIGLIORINI，S. M. S. 2006. Indústria paranaense: formação, transformação econômica a partir da década de 1960 e distribuição espacial da indústria no início do século XXI. Revista Eletrônica Geografar, Curitiba, v. 1, n. 1, p. 62-80. Disponível em: http://ojs.c3sl.ufpr.br/ojs2/index.php/ geografar/article/download/6843/4859. Acesso em: 20.nov.2012.

MILLS, C. W. 1981. A elite do poder. Rio de Janeiro: J. Zahar.

MOISÉS, J. A. \& CARNEIRO, G. P. 2010. Democracia, desconfiança política e insatisfação com o regime - o caso do Brasil. In: MOISÉS, J. A. (org.). Democracia e confiança: por que os cidadãos comuns desconfiam das instituições. São Paulo: USP.

OFFERLÉ, M. 2009. Sociologie des organizations patronales. Paris: La Découverte.

OLIVEIRA, D. 2001. Urbanização $e$ industrialização no Paraná. Curitiba: SEED.

POHLMANN, M.; LIEBOLD, R.; BÄR, S.; SALLMON, C.; SCHANNE, S. \& SCHMIDT, G. 2010. A elite econômica na mudança social. Heidelberg: Universidade de Heidelberg. Digit.

PUTNAM, R. D. 1976. The Comparative Study of Political Elites. New Jersey: Prentice Hall.

TRINTIN, J. G. 2001. A economia do Paraná: 1985 a 1998. Campinas. Tese (Doutorado em Economia). Universidade Estadual de Campinas.

\section{OUTRASFONTES}

BRASIL. MDIC. 2011. Sistema AliceWEB. Disponível em: http://aliceweb.desenvolvimento.gov.br/. Acesso em: 20.nov.2012.
IPARDES. 2011. Consulta a indicadores. Disponível em: www.ipardes.gov.br. Acesso em: 19.nov.2012. 
IBGE. 2011. Caderno de indicadores. Disponível em: http://www.ibge.gov.br/home/mapa_site/ mapa_site.php\#indicadores. Acesso em: 4.dez.2012.

REDE EMPRESARIAL. 2012. Rede de participação política. Federação das Indústrias do Paraná. Disponível em: http:// www.redeempresarial.org.br/. Acesso em: 4.dez.2012.

\section{ANEXO 1}

\section{QUESTIONÁRIO}

\section{PRIMEIRO BLOCO: PERFIL E TRAJETÓRIA}

1- Qual é a sua data de nascimento?

2- Qual o seu local de nascimento?

3- Por favor, olhando as opções contidas neste anexo, o (a) $\mathrm{Sr}$ (a) poderia responder qual é a sua religião?
1. Católica romana
7. Protestante
2. Católica ortodoxa
8. Mulçumana

3. Religiões evangélicas

9. Sem religião

4. Religiões de origem africana 10. Outra. Qual? :

5. Espírita

11. NS

6. Judaísmo

12. NR

4- Utilizando os critérios do IBGE, o (a) Sr (a) poderia informar qual é a sua cor ou raça?

1. Branca 4. Amarela

2. Preta 5. Indígena

3. Parda 9. NR

5- Por favor, observe as opções contidas neste anexo e indique a ocupação que o (a) $\operatorname{Sr}$ (a) exerceu por mais tempo?

1. Proprietário rural com até 50 hectares

2. Proprietário rural entre 50 e 200 hectares

3. Proprietário rural com mais de 200 hectares

4. Proprietário urbano (comércio, serviço e indústria) com até 9 empregados

5. Proprietário urbano (comércio, serviço e indústria) entre 10 e 49 empregados

6. Proprietário urbano (comércio, serviço e indústria) com 50 ou mais empregados

7. Advogado atuante

8. Profissional liberal (engenheiro, médico etc. com escritório próprio)

9. Altos cargos do setor público (diretor de empresa/banco estatal, delegado da receita estadual, desembargador, juiz etc.)

10. Funcionário público de médio ou baixo escalão

11. Professor universitário de instituição pública

12. Professor universitário de instituição privada 
13. Professor de outros níveis de instituição pública

14. Professor de outros níveis de instituição privada

15. Comunicador (radialista, apresentador de programas de TV)

16. Jornalista (imprensa escrita ou falada)

17. Trabalhador assalariado de empresa privada (manual ou qualificado, registrado ou informal, temporário ou permanente)

18. Executivo de empresa privada

19. Político

20. Militar

21. Não exerceu nenhuma atividade

22. NR

6- O (a) $\mathrm{Sr}$ (a) exerceu alguma outra ocupação durante o exercício do cargo?

1. Sim, Qual? 2. Não 9. NR

7- Qual é seu nível de escolaridade?

1. Sem instrução

2. Fundamental incompleto

3. Fundamental (1a à 8a série; antigo primário/ginásio)

4. Médio incompleto

5. Médio ( $1^{\circ}-3^{\circ}$ colegial; antigo secundário/científico)

6. Superior incompleto Qual? Instituição: Ano de conclusão

7. Superior ( $3^{\circ}$ grau) Qual? Instituição: Ano de conclusão:

8. Especialização incompleto: Qual? Instituição: Ano de conclusão

9. Especialização completo: Qual? Instituição: Ano de conclusão:

10. Mestrado incompleto: Qual? Instituição: Ano de conclusão

11. Mestrado completo: Qual? Instituição: Ano de conclusão Instituição: Ano de

12. Doutorado incompleto: Qual? conclusão

13. Doutorado completo: completo: Qual? conclusão Instituição: Ano de

14. NR

8- Por favor, observe as opções contidas neste anexo e indique a ocupação que o seu pai exerceu por mais tempo?

1. Proprietário rural com até 50 hectares

3. Fundamental (1a à 8a série; antigo primário/ginásio) 
4. Médio incompleto

5. Médio ( $1^{\circ}-3^{\circ}$ colegial; antigo secundário/científico)

6. Superior incompleto

7. Superior ( $3^{\circ}$ grau; universitário)

8. Especialização

9. Mestrado

10. Doutorado

11. NS NR

10- O Sr. já assumiu algum cargo político ou administrativo público, eletivo ou não?

1. Não.

2. Sim, Qual? Em que ano?

11- O Sr. já assumiu algum cargo ou foi membro de outras entidades, sejam de representação empresarial ou de qualquer outra natureza (instituições religiosas, culturais, Rotary, Lyons, maçonaria etc.?).

12- Atualmente o Sr. ocupa cargo ou é membro de outras entidades, sejam de representação empresarial ou de qualquer outra natureza (instituições religiosas, culturais, Rotary, Lyons, maçonaria etc.?)

13- Em relação à filiação a partidos políticos, qual (is) o Sr. já foi ou está filiado, em ordem cronológica decrescente:

\section{SEGUNDO BLOCO: CULTURA POLÍTICAE ATITUDES}

14- A seguir, serão indicados alguns ASPECTOS GERAIS DA DEMOCRACIA e nós gostaríamos que o Sr. nos dissesse se cada um dele é: I- essencial, ou seja, necessário à democracia; II- Não é essencial, mas é desejável; III- É dispensável ou não desejável, e por quê ?:

\begin{tabular}{|c|c|c|c|c|}
\hline & $\begin{array}{c}\text { É essencial } \\
e \\
\text { necessário }\end{array}$ & $\begin{array}{c}\text { Não é } \\
\text { essencial, } \\
\text { mas é } \\
\text { desejável }\end{array}$ & $\begin{array}{c}\text { Dispensável } \\
\text { ou não } \\
\text { desejável }\end{array}$ & Por quê? \\
\hline \multicolumn{5}{|l|}{$\begin{array}{l}\text { A participação da população nos processos } \\
\text { decisórios fundamentais }\end{array}$} \\
\hline \multicolumn{5}{|l|}{$\begin{array}{l}\text { A adesão da população aos valores } \\
\text { democráticos }\end{array}$} \\
\hline \multicolumn{5}{|l|}{$\begin{array}{l}\text { A competência administrativa por parte dos } \\
\text { governos }\end{array}$} \\
\hline \multicolumn{5}{|l|}{ O respeito às autoridades constituídas } \\
\hline \multicolumn{5}{|l|}{ A liberdade de mercado e de iniciativa } \\
\hline $\begin{array}{l}\text { Equilíbrio entre o poder Executivo e o poder } \\
\text { Legislativo na gestão da sociedade }\end{array}$ & & & & \\
\hline
\end{tabular}


15- No caso brasileiro, se tivéssemos que optar, o que seria mais importante: o bom funcionamento das instituições ECONÔMICAS ou o bom funcionamento das instituições POLÍTICAS? Justifique:

16- A democracia é uma forma eficaz de solucionar crises que ocorrem na sociedade e na política?

SIM NÃO Justifique

17- O Sr. acredita que reformas nas instituições políticas representativas poderiam alterar a forma como o Governo toma as decisões relacionadas aos rumos gerais da economia?

SIM NÃO Justifique

18- Algumas pesquisas indicam que a população brasileira avalia positivamente a democracia e negativamente instituições por excelência democráticas, tais como o poder Executivo, o Poder Legislativo, os partidos etc. O Sr. compartilha desta avaliação por parte da população?

SIM NÃO Justifique

19- Em sua opinião, a democracia brasileira está ou não fortalecida e consolidada, portanto pouco sujeita a crises que possam levar ao seu abandono?

SIM NÃO Justifique

20- Em suas atividades especificamente empresariais, o Sr. acredita que exista um nível de confiança alto ou baixo entre agentes envolvidos (stakeholdes, fornecedores, clientes, trabalhadores etc.)?

ALTO BAIXO Justifique

21- Em relação ao grau de confiança, avalie as seguintes instituições:

\begin{tabular}{|c|c|c|c|c|}
\hline & Confia & Confia pouco & Não confia & Justifique \\
\hline \multicolumn{5}{|l|}{ Poder Executivo federal } \\
\hline \multicolumn{5}{|l|}{ Poder Executivo estadual } \\
\hline \multicolumn{5}{|l|}{ Poder Executivo municipal } \\
\hline \multicolumn{5}{|l|}{ Poder Judiciário federal } \\
\hline \multicolumn{5}{|l|}{ Poder Judiciário estadual } \\
\hline \multicolumn{5}{|l|}{ Ministério Público federal } \\
\hline \multicolumn{5}{|l|}{ Ministério Público estadual } \\
\hline \multicolumn{5}{|l|}{ Senado } \\
\hline \multicolumn{5}{|l|}{ Câmara dos Deputados } \\
\hline \multicolumn{5}{|l|}{ Assembléia Legislativa de seu estado } \\
\hline \multicolumn{5}{|l|}{ Câmara de Vereadores } \\
\hline \multicolumn{5}{|l|}{ Partidos políticos } \\
\hline \multicolumn{5}{|l|}{ Sindicatos de trabalhadores } \\
\hline \multicolumn{5}{|l|}{ Entidades sindicais patronais } \\
\hline Associações patronais & & & & \\
\hline
\end{tabular}

22- Enquanto instituições e não apenas em relação aos mandatos atuais, como o Sr. avalia o desempenho das instituições abaixo:

\begin{tabular}{|l|l|l|l|l|}
\hline & Bom & Satisfatório & Ruim & Justifique \\
\hline Presidência da República & & & \\
Governo do seu estado & & & \\
Banco do Brasil & & & \\
Bndes & & & \\
Banco Central & & & \\
Sistema Partidário & & & \\
Sistema eleitoral & & & \\
\hline
\end{tabular}


23- Considerando os principais temas do debate sobre a reforma política, gostaríamos de saber se o Sr. é a favor ou contra das seguintes propostas, e porque.

\begin{tabular}{|c|c|c|c|}
\hline & Favor & Contra & Justifique \\
\hline \multicolumn{4}{|l|}{ Financiamento público de campanha } \\
\hline \multicolumn{4}{|l|}{ Voto distrital } \\
\hline \multicolumn{4}{|l|}{ Fidelidade partidária } \\
\hline \multicolumn{4}{|c|}{$\begin{array}{l}\text { Fim da reeleição para cargos do poder Executivo (presidente, } \\
\text { governador e prefeito) }\end{array}$} \\
\hline \multicolumn{4}{|l|}{ Voto obrigatório } \\
\hline \multicolumn{4}{|l|}{ Constituinte exclusiva para fazer a reforma política } \\
\hline Outro. Qual? & & & \\
\hline
\end{tabular}

24- O principal fator para a alta taxa de juros básica (Selic), em sua opinião, é:

1- O controle da inflação

2- A pressão política do setor financeiro

3- Falta de ousadia da equipe econômica

4- Outra. Qual?:

25- É positiva a presença de bancos públicos no sistema financeiro para a oferta de crédito e o crescimento da economia.

0- Discorda 1- Concorda

26- Nas ações governamentais de incentivo à economia, como por exemplo, a concessão de créditos pelos bancos públicos, deve ser dada prioridade às empresas de controle acionário nacional.

0- Discorda 1- Concorda

27- As alianças políticas com os sindicatos de trabalhadores são importantes para a expansão do setor produtivo.

0- Discorda 1- Concorda

\section{TERCEIRO BLOCO: AÇÃO POLÍTICAE COMPORTAMENTO}

28- Qual é segmento do setor empresarial representado pela entidade que é mais atuante?

29- O Sr. entende que há a necessidade do empresariado de formular um projeto seu para o Estado e a sociedade brasileiros?

SIM NÃO JUSTIFIQUE

30- $\mathrm{Na}$ defesa dos interesses de sua entidade/empresa predominam as ações isoladas ou articuladas com outras entidades/empresas?

1. Articuladas 2. Isoladas 
31- Em sua opinião, haveria a necessidade de uma ENTIDADE que representasse o conjunto dos interesses de todo os setores do empresariado brasileiro frente ao Governo e à sociedade?

1. $\operatorname{Sim}$ 2. Não

32- Sua entidade/empresa possui alguma atuação em relação a questão do aperfeiçoamento das instituições políticas ou da reforma política?

1. Sim 2. Não

33- Nesta questão estamos interessados em saber SE EXISTEM e COMO SE DÃO as relações da sua entidade/empresa com algumas INSTITUIÇÕES ESTATAIS, levando em conta os contatos de MAIOR IMPORTÂNCIA, a FREQÜÊNCIA, a FORMA ou o MEIO utilizado para contato com as instituições, o grau de SUCESSO e os principais ASSUNTOS tratados.

\begin{tabular}{|c|c|c|c|c|c|c|c|c|}
\hline & Não & Sim & $\begin{array}{l}\text { Pouca } \\
\text { frequên- } \\
\text { cia }\end{array}$ & $\begin{array}{l}\text { Muita } \\
\text { frequên- } \\
\text { cia }\end{array}$ & $\begin{array}{c}\text { Forma } \\
\text { ou } \\
\text { meio } \\
\text { de } \\
\text { contato }\end{array}$ & $\begin{array}{c}\text { Bem } \\
\text { sucedido }\end{array}$ & $\begin{array}{l}\text { Mal } \\
\text { suce- } \\
\text { dido }\end{array}$ & $\begin{array}{l}\text { Assun- } \\
\text { tos }\end{array}$ \\
\hline \multicolumn{9}{|l|}{$\begin{array}{l}\text { IV.1. Governos } \\
\text { estaduais } \\
\text { (Governador e } \\
\text { secretarias) }\end{array}$} \\
\hline \multicolumn{9}{|l|}{$\begin{array}{l}\text { IV.2. } \\
\text { Assembléias } \\
\text { Legislativas } \\
\text { (estaduais) }\end{array}$} \\
\hline \multicolumn{9}{|l|}{$\begin{array}{l}\text { IV.3. } \\
\text { Presidência da } \\
\text { República }\end{array}$} \\
\hline \multicolumn{9}{|l|}{$\begin{array}{l}\text { IV.4. Ministério } \\
\text { da Fazenda }\end{array}$} \\
\hline \multicolumn{9}{|l|}{$\begin{array}{l}\text { Ministério do } \\
\text { Desenvolviment } \\
\text { o, Indústria e } \\
\text { Comércio } \\
\text { Exterior }\end{array}$} \\
\hline \multicolumn{9}{|l|}{$\begin{array}{l}\text { IV.5. Órgãos, } \\
\text { secretarias e } \\
\text { agências } \\
\text { federais }\end{array}$} \\
\hline \multicolumn{9}{|l|}{$\begin{array}{l}\text { IV.6. Banco do } \\
\text { Brasil }\end{array}$} \\
\hline \multicolumn{9}{|l|}{ Bndes } \\
\hline \multicolumn{9}{|l|}{$\begin{array}{l}\text { IV.7. Senado } \\
\text { Federal }\end{array}$} \\
\hline \multicolumn{9}{|l|}{$\begin{array}{l}\text { IV.8. Câmara } \\
\text { dos Deputados }\end{array}$} \\
\hline \multicolumn{9}{|l|}{ Outros (qual?) } \\
\hline Outros (qual?) & & & & & & & & \\
\hline
\end{tabular}

34- Como o senhor vê a disputa entre as entidades de classe que representam o empresariado pelo direcionamento dos investimentos do Estado brasileiro? 
35- Considerando que o lobby e o financiamento de campanha são práticas regulares e importantes nas democracias, qual das duas se mostrou mais eficaz em relação aos interesses de sua ENTIDADE?

( ) Lobby

( ) Financiamento de campanha

( ) Nenhuma das duas. Qual?

36- Considerando as eleições gerais de 2010, quais serão as ações que, de fato, sua entidade/empresa tomará em relação aos seguintes candidatos:

Presidente da República

Governador

Senador

Deputado Federal

Deputado Estadual

Muito obrigado pela participação

ANEXO 2

TABELA DE VALORES POLÍTICOS

\begin{tabular}{|c|c|c|c|c|}
\hline & $\begin{array}{c}\text { É essencial e } \\
\text { necessário }\end{array}$ & $\begin{array}{c}\text { Não é } \\
\text { essencial, } \\
\text { mas é } \\
\text { desejável }\end{array}$ & $\begin{array}{c}\text { Dispensável } \\
\text { ou não } \\
\text { desejável }\end{array}$ & N.R. \\
\hline $\begin{array}{l}\text { A participação da população nos processos } \\
\text { decisórios fundamentais }\end{array}$ & 7 & 1 & - & 1 \\
\hline $\begin{array}{l}\text { A adesão da população aos valores } \\
\text { democráticos }\end{array}$ & 8 & - & - & - \\
\hline $\begin{array}{l}\text { A competência administrativa por parte dos } \\
\text { governos }\end{array}$ & 8 & - & - & 1 \\
\hline $\mathrm{O}$ respeito às autoridades constituídas & 8 & - & - & 1 \\
\hline A liberdade de mercado e de iniciativa & 8 & - & - & 1 \\
\hline $\begin{array}{l}\text { Equilíbrio entre o poder Executivo e o poder } \\
\text { Legislativo na gestão da sociedade }\end{array}$ & 8 & - & - & 1 \\
\hline
\end{tabular}

TABELA DE GRAU DE CONFIANÇA

\begin{tabular}{|c|c|c|c|c|}
\hline & Confia & Confia pouco & Não confia & N.R \\
\hline Poder Executivo federal & 3 & 5 & - & 1 \\
\hline Poder Executivo estadual & 2 & 5 & 1 & 1 \\
\hline Poder Executivo municipal & 4 & 3 & 1 & 1 \\
\hline Poder Judiciário federal & 6 & 2 & - & 1 \\
\hline Poder Judiciário estadual & 6 & 2 & - & 1 \\
\hline Ministério Público federal & 7 & 1 & - & 1 \\
\hline Ministério Público estadual & 6 & 2 & - & 1 \\
\hline Senado & 2 & 5 & 1 & 1 \\
\hline Câmara dos Deputados & 2 & 5 & 1 & 1 \\
\hline $\begin{array}{l}\text { Assembléia Legislativa de seu } \\
\text { estado }\end{array}$ & 1 & 4 & 3 & 1 \\
\hline Câmara de Vereadores & 2 & 5 & 1 & 1 \\
\hline Partidos políticos & 1 & 4 & 3 & 1 \\
\hline Sindicatos de trabalhadores & 2 & 5 & 1 & 1 \\
\hline Entidades sindicais patronais & 8 & - & - & 1 \\
\hline Associações patronais & 8 & - & - & 1 \\
\hline
\end{tabular}




\begin{tabular}{|l} 
TABELADE GRAUDE SATISFAÇÃO \\
\begin{tabular}{|l|c|c|c|c|}
\hline & Bom & Satisfatório & Ruim & N.R. \\
\hline Presidência da República & 2 & 4 & 2 & 1 \\
Governo do seu estado & 1 & 1 & 6 & 1 \\
Banco do Brasil & 3 & 4 & 1 & 1 \\
Bndes & 3 & 5 & - & 1 \\
Banco Central & 6 & 2 & - & 1 \\
Sistema Partidário & - & 3 & 5 & 1 \\
Sistema eleitoral & 2 & 2 & 4 & 1 \\
\hline
\end{tabular}
\end{tabular}

TABELA DE REFORMA POLÍTICA

\begin{tabular}{|l|c|c|c|}
\hline & Favor & Contra & N.R. \\
\hline Financiamento público de campanha & 4 & 4 & 1 \\
Voto distrital & 7 & 1 & 1 \\
Fidelidade partidária & 7 & 1 & 1 \\
Fim da reeleição para cargos do poder Executivo & 6 & 2 & 1 \\
Voto obrigatório & 1 & 7 & 1 \\
Constituinte exclusiva para fazer a reforma política & 6 & 2 & 1 \\
Outro. Qual? & - & - & 1 \\
\hline
\end{tabular}




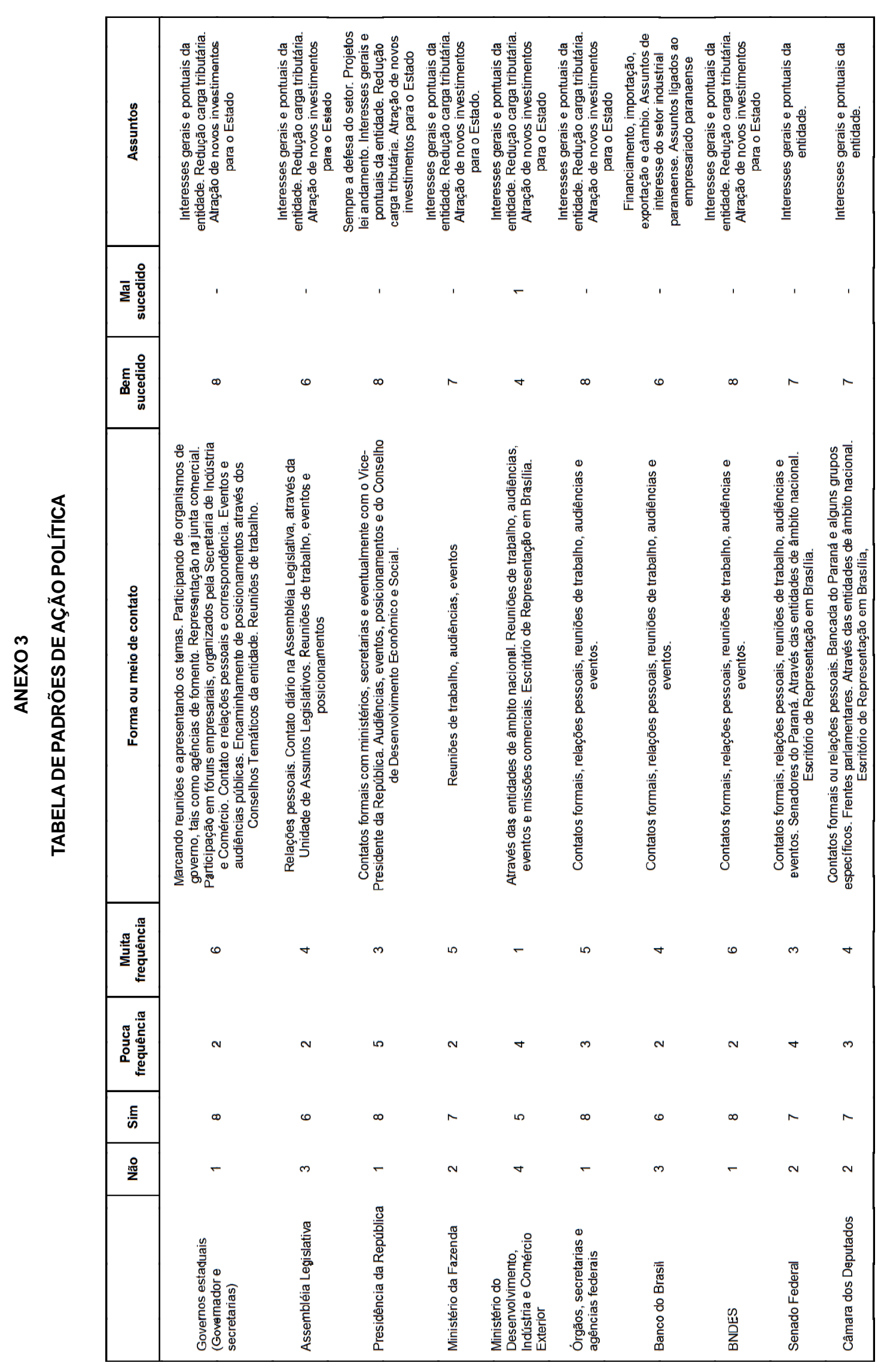


This document was created with Win2PDF available at http://www.win2pdf.com. The unregistered version of Win2PDF is for evaluation or non-commercial use only. This page will not be added after purchasing Win2PDF. 